\title{
The Theoretical Logic, Scientific Connotation and Realization Path of the Rural Revitalization Strategy
}

\author{
Liao Cairong, ${ }^{1, *}$, Chen Meiqiu ${ }^{2}$ \\ ${ }^{1}$ Derpartment of Economics \& Management, Jiangxi Agricultural University, Nanchang, China \\ ${ }^{2}$ Derpartment of Land Resources \& Environment, Jiangxi Agricultural University, Nanchang, China
}

Email address:

624046080@qq.com (Liao Cairong),cmq12@263.com (Chen Meiqiu)

${ }^{*}$ Corresponding author

To cite this article:

Liao Cairong, Chen Meiqiu. The Theoretical Logic, Scientific Connotation and Realization Path of the Rural Revitalization Strategy. International Journal of Agricultural Economics. Vol. 4, No. 1, 2019, pp. 10-18. doi: 10.11648/j.ijae.20190401.12

Received: December 3, 2018; Accepted: December 20, 2018; Published: January 19, 2019

\begin{abstract}
This paper analyzes the theoretical logic, scientific connotation and realization path of the rural revitalization strategy in China. The methods include literature survey method, observation method, speculative method, behavioral research method, historical research method, conceptual analysis method and comparative research method. The result shows that the rural revitalization strategy is a new strategy, deployment and requirement for the Party Central Committee's "Three Rural" work in the new era, with "strategy" as its core, "revitalization" as its key, and "rural" as its target. The conclusion shows that it is necessary to fully understand the essence, general requirements, main objectives and contents of this strategy. To implement this strategy, it is necessary to adhere to the top-level design and well design these strategic plans. to strengthen the system supply and promote the building of the "Five-sphere Integrated Plan". It requires to do more to advance supply-side structural reform in agriculture and work faster to achieve agricultural and rural modernization. It is essential to ensure the principal status of the people and to rely on and serve the rural population. China should grasp the core elements of "people", "land" and "money", and promote steady growth of the rural revitalization strategy.
\end{abstract}

Keywords: Rural Revitalization Strategy, Theoretical Logic, Scientific Connotation, Realization Path

\section{Introduction and Literature Review}

The 19th National Congress of the Communist Party of China takes the rural revitalization strategy as part of committing to the new development philosophy and building a modern economic system. This is the Party's new "Three Rural" work ${ }^{1}$ as socialism with Chinese characteristics has crossed the threshold into a new era. A concentrated indication of expression of Xi Jinping's "Three Rural" thoughts, it is a major strategic deployment based on a deep understanding of the new stage, new laws and new tasks of the "Three Rural" development in the new era, reflecting the integral requirements of the agricultural development.

40 years since the reform and opening up, China's agriculture and rural areas have made historic achievements along with the progress of the other national undertakings.

1 the issues relating to agriculture, rural areas, and farmers.
Especially since $18^{\text {th }}$ national congress, the Party Central Committee has issued a series of policies to strengthen agriculture and benefit farmers, achieving the bumper harvest of agriculture, increasing farmer's income and maintaining the harmonious and stable situation in rural areas. The food production has achieved a historic 12-year growth with 600 million metric tons in 2016. The farmers' income has maintained a positive growth with the urban-rural income disparity narrowed to $2.72: 1$ in 2016; remarkable achievements have been made on targeted poverty reduction, with more than 60 million farmers stably lifted out of poverty, and the poverty population reduced to 43.35 million according to the 2010 standard; there has been a great achievement on the construction of the new socialist countryside, along with the drastic changes in rural areas on the great improvement in the infrastructure, such as roads and bridges, and in education, medical care, social welfare and culture, etc.

However, the "Three Rural" issues still remain a challenge, especially the synchrony of the "Three Rural" and "Four 
Modernizations" 2. The new three rural issues (rural depopulation, rural marginalization and rural aging) are becoming increasingly outstanding. The mobility of the rural labor force accompanied with the severe loss of rural talents leave the village cottages abandoned and dilapidated. There are many desolate places in rural areas similar to those described in "Doctor's Returning Home Notes" and "Dr. Homecoming Record"; in many places, farmers' incomes mainly depend on non-agricultural income from migrant workers while most of those who stay in rural areas are the elderly, women and children, leaving the farmlands barren. Thus, the questions of "who will till the land" and "how to till the land" are becoming quite prominent; Problems like the underdeveloped agricultural sector, the weak competitiveness of agricultural products and the rural pollution are quite outstanding. The imbalance of the urban-rural development shows that the single flow of the resources from the rural to the urban has not been fundamentally reversed. The "Three Rural" issues have become a weak point in building a moderately prosperous society in all respects and striving for basically achieving modernization and the national rejuvenation.

Globally, some developed countries like Germany, France, US, Japan and S. Korea also went through the rural recession or crisis $^{3}$; Besides China, many developing countries like India, S. Africa, Brazil, Mexico are also experiencing the recession and crisis in the rural areas. This is typically reflected on the fact that many young adults are leaving countryside for cities in many developing countries and there are many prominent slums in the cities, along with the rural development lagging behind and urban-rural gap expanded. Thus, rural recession has now become the global challenge faced by all the mankind and an important aspect in worldwide governance. "The rural recession is a common challenge shared by the entire world. We need to focus on promoting rural revitalization in the process of global urbanization.'[1]

The rural recession is quite prominent in China today, which leads to a vicious circle. Thus, the initiation of rural revitalization strategy is not only timely but also particularly important and necessary. It is an important strategic decision made by Chinese authorities for the "Four Modernizations", rural-urban integration and building a moderately prosperous society in all respects [2].

2 "Four Modernizations" is to strengthen the sectors of agriculture, industry, science and technology and national defense.

3 From the perspective of these developed countries at the time, their level of modernization had already been particularly high, but whether with comparative advantages or disadvantages in agriculture or whether with strong exports or imports, these countries' modernization caused the sparse and aging rural population, especially the aging of the labor force, for example, those agricultural managers in the United States and Japan were mostly around 70 years old However, these countries have reenergized the rural areas by adopting certain rural development and revitalization plans, such as the Development of German Village Competition Program of the 1960s, the French Rural Development Programme of 2000-2006, and the "village movement" Saemaeul Movement" "new rural village" implemented respectively in Japan, South Korea and Taiwan from the 1970s. These programs have achieved the agricultural modernization and narrowed the gap of the income and living standards between rural and urban residents, basically realizing the urban-rural economic integration.
There are abundant domestic and overseas researches upon the rural revitalization or related areas like rural rejuvenation, construction, remodeling and development. In the study of rural revitalization elements: Through the research upon rural entrepreneurs in North Florida, American scholar Gladwin $\mathrm{CH}$ et al [3] claim that rural entrepreneurship plays a key role in rural revitalization; Johnson TG [4] believes that the development of rural finance is the key to the rural revitalization; Based on the survey of rural community development alliances in the United States and Canada, Korsching P [5] believes that multi-community collaboration is particularly important for rural revitalization; in the aspect of principal agents of rural revitalization, Greene MJ [6], through analyzing the initiative of agricultural diversified development, believes that the government plays an irreplaceable part in rural revitalization; Ayobami OK [7] studies the role of tourism volunteers in rural revitalization; Kawate $\mathrm{T}$ [8] analyzes the role of the rural rejuvenation and reform organizations in the rural revitalization and development in the contemporary Japan. In the case studies, Wood RE [9], Carr PJ [10], etc., Z Li [11], Miletić GM [12], etc., Nonaka A Ono $\mathrm{H}$ [13] respectively introduce the experiences in the plans and practices of rural revitalization in East Asia, Croatia, Japan and some other countries; In the study of rural revitalization theories, scholars like Bai X et al [14], McLaughlin K et al [15], Liu Y et al [16], analyze and discuss the relevant theories of rural revitalization by combining with practice or with research fields from the perspective of rural development and global governance. However, in China, before the national initiation of the rural revitalization strategy, scholars mainly focus on aspects like rural construction, development or economic revitalization. Huang Jiyu [17], Xiang Jiquan [18], Huang Zuhui [19], Pan Jiaen [20] point out some basic and theoretical research issues in agriculture and rural areas from the perspective of past, present and future, and sort out some aspects of rural construction. Chen Xiwen [21], Han Jun [22], Liu Yansui [23] explore the current strategic layout of China's agricultural and rural issues, especially the major problems of China's urban and rural development in the new era; Faced with the recession or revival debate brought by the "Three Rural" issues, Wang Yong [24], Zhang Yong [25], Pan Jiaen [26], Xu Yong [27] research on the rural decay, rural rejuvenation, urban-rural contradictions, and urban-rural imbalances, etc. He Xuefeng [28] directly points out that the current differentiated rural areas bring complicated governance problems; some social scholars [29-31] discuss the contemporary value, rural social order reconstruction and rural rejuvenation under the era of the social transformed rural construction; When discussing the process of urban-rural integration, Zheng Fengtian [32], Liu Shouying [33] underscore that the "urban and rural China" in the new era must be transformed from one-way urbanization to urban-rural interaction; For the benefit of the great national rejuvenation, what is the roadmap of the rural revitalization? He Huili [34] points out that this is a road to the rural rejuvenation in contemporary China; Cai Wei [35] believes 
that it is the road of people-centered urbanization; While Zhang Hongyu [36] claims that the beautiful rural construction needs to retain the nostalgia. In the case study, Wei Guanglong [37], Zhao Chen [38], Gao Huizhi, etc. [39] respectively analyze the cases of rural revitalization in different areas of China, summing up the main practices, achieving some results, and obtaining some successful inspirations.

On the basis of literature review, it can be seen that there are not many researches on the theme of "rural revitalization strategy" in the academic circles, especially in China. This might be due to the fact that this strategy has recently been put forward, and the academic circles are lacking in the rational interpretation of "rural revitalization" or related issues. In order to have the deep understanding and accurate comprehension of the rural revitalization strategy, it is necessary to explore the theoretical logic, scientific connotation and realization path of this strategy.

\section{Theoretical Logic of Rural Revitalization Strategy}

Analysis of the theoretical logic can be carried out in the following ways:

\subsection{The Core of the Rural Revitalization Strategy Is Embodied in the "Strategy"}

The implementation of the rural revitalization strategy is Party's major judgment and decision of the new situations, tasks and goals of the "Three Rural" development in the new era of socialism with Chinese characteristics. Different from any previous agricultural and rural development policy, "rural revitalization" is put forward as a "strategy", which reflects a macroscopic, systematic, comprehensive and holistic development strategy.

\subsubsection{Strategic Thoughts}

The rural revitalization strategy is a concentrated expression of Xi Jinping's "Three Rural" thoughts and an important part of Xi Jinping Thought on Socialism with Chinese Characteristics for a New Era. General Secretary Xi Jinping highlights: "If China wants to be strong, agriculture must be strong. If China wants to be beautiful, the countryside must be beautiful. If China wants to get rich, the farmers must get rich." "We must never ignore agriculture, forget farmers, or be indifferent to the countryside." "We must unswervingly deepen rural reform, accelerate rural development, and maintain rural harmony and stability." The rural revitalization strategy proposed by the 19th National Congress profoundly clarifies the strategic position, working methods and important measures of "Three Rural" work. As the foundation rules to do the "Three Rural" work in the new era, this strategy scientifically answers many theoretical and practical issues in the "Three Rural" work in the new era.

\subsubsection{Strategic Entity}

On the one hand, the state is by logic the main entity to implement this national strategy. For a long time, in order to support national industrialization and urban priority development, China's agricultural and rural farmers have made tremendous contributions and enormous sacrifices, causing the long-term dualistic urban-rural separation. The "Three Rural" issues have become the most acute problem in the unbalanced and inadequate development in China. Since the reform and opening up 40 years ago, China's comprehensive national power and economic strength have been greatly enhanced. China now has the adequate material and technical conditions to support the "Three Rural" development to achieve the rural revitalization. On the other hand, people are the principal entity that rural revitalization strategy should rely upon. The $19^{\text {th }}$ National Congress states: "Commit to a people-centered approach. The people are the creators of history; they are the fundamental force that determines our Party and country's future. We must ensure the principal status of the people." In the implementation of the rural revitalization strategy, it is necessary to rely on the rural population as the principal strategic entity. The promotion of this strategy must be farmer-centered, relying on and serving the majority of farmers.

\subsubsection{Strategic Contents}

The strategic contents are macro, comprehensive, multidimensional and diverse. The rural revitalization strategy is not only to re-think, re-recognize and re-explore the long existing "Three Rural" issues in China, but also to re-start, re-deploy and re-promote these issues at the new historical starting point. Its strategic contents do not only include the agricultural economic construction, but also political, cultural, social, and ecological advancement; It has not only focused on the key issues of "people", "land" and "money" that need to be solved in the current rural revitalization, but also seriously answered some specific questions, such as "Rural land contracting practices will remain stable and unchanged on a long-term basis; the current round of contracts will be extended for another 30 years upon expiration". This suggests that after the current round of contracting expires in 2028, it will be extended for another 30 years, which implies that, combined with the former contracting period, it will be a 75-year land contracting period at around 2058. Along with a long-lasting land system, it provides farmers with an expectation of relatively stable future, which is conducive to the long-term stability of the contracting relationship. It can play the role of "stability anchor", which not only gives the farmers a reassurance, but also helps the capital investment to go to the countryside, so as to synchronize with the achievement of modernization in all respects.

\subsection{The Key to the Rural Revitalization Strategy Is "Revitalization"}

The aim of the strategy is to achieve rural development and prosperity, and to achieve agricultural and rural modernization. The "revitalization" can be interpreted from three dimensions. 


\subsubsection{Time Dimension}

The implementation of the rural revitalization strategy has come to a new historical starting point. As the socialism with Chinese characteristics has entered a new era, the principal contradiction facing Chinese society has evolved. What China now faces is the contradiction between unbalanced and inadequate development and the people's ever-growing needs for a better life. China's reform and opening up has begun with the rural reform. 39 years since the reform and opening up, China's agricultural productivity has been greatly improved, however, agricultural modernization is lagging behind other modernizations. The principal contradiction has now evolved to be the one between unbalanced and inadequate development and the people's ever-growing needs for a better life. Therefore, the proposal of the "revitalization" does not only show the consistent continuation of the Party and the government's priority in the "Three Rural" work, but also reflect the Party and the state's new call for the future when dealing with the "Three Rural" issues in the new era.

\subsubsection{Spatial Dimension}

From a new spatial dimension, the Party Central Committee takes a full comprehensive approach to the coordinated development between the new "Three Rural" spatial structure, rural and urban areas, agricultural and rural modernization, and other "Three Modernizations". The PCC has recently proposed this rural revitalization strategy on the basis of the major international and domestic situations. The 19th National Congress points out that it is necessary to promote the simultaneous development of new industrialization, IT application, urbanization, and agricultural modernization; China must continue to adhere to and expand opening up, and actively participate in and promote the process of economic globalization. On the one hand, closely related to the domestic economic and social development, rural revitalization is the development of symbiosis and co-prosperity in urban and rural areas, the "Four Modernizations" and the "Five-sphere Integrated Plan" ${ }^{5}$; On the other hand, China's rural revitalization strategy cannot be separated from the international community. Agricultural development, product exportation, rural governance and other issues are not only domestic issues, but also global ones to a certain extent. China's rural revitalization strategy is an integral component of the global governance system. Its implementation can fully draw on the successful experiences and practices of rural development in many other countries.

\subsubsection{Conceptual Dimension}

The rural revitalization strategy is the concentrated performance of implementing the new development concept of "innovation, coordination, green, openness, and sharing". First, it gives priority to the development. This strategy maintains the Party and the government's "top priority" in the "Three Rural" issues. With this strategy the Party and the government not only reaffirm the top priority status of "Three Rural" issues among all the works, but also propose "continuing to prioritize the development of agriculture and rural areas" for the first time. This "priority" is reflected on the great support and effort of narrowing the gap in urban-rural areas so as to ensure that farmers have more sense of gaining in the shared growth, and on the concept of new development and sharing. Second, it proposes an integrated development. In recent years, the gap between urban and rural areas has been narrowed, and the number of the rural poor has decreased. This is the result of the implementation of new concepts in China in recent years. The rural revitalization strategy is transforming from the coordinated urban-rural development to the integrated urban-rural development, which further demonstrates the new concept of coordinated development. Third, the rural revitalization strategy is different from many former development strategies which only focus on some individual agriculture, rural areas or farmers. "Revitalization" aims at the overall revitalization of the countryside. This does not only include rural areas, but also townships, which reflects the overall development of villages, towns and cities. It aims at the development of urban-rural integration and shows the concept of the urban-rural mutual promotion and integrated development.

\subsection{The Target of the Rural Revitalization Strategy Lies in the "Rural"}

The rural revitalization strategy's target is at the rural area. As an organic whole, the rural area is an extremely complex mega-system, which contains extremely comprehensive contents ecologically, economically and socially [40].

\subsubsection{Achieve the Intensive Development}

The 20-word general requirement for implementing the rural revitalization strategy, "thriving businesses, pleasant living environments, social etiquette and civility, effective governance, and prosperity", intends to achieve the rural intensive development. Comparing with the 20-word policy of building new socialist rural areas in 2005: "the production development, the life ampleness, the local custom civilization, the village neatness, and the management democracy", it can be seen that both expressions, despite their differences, are a complete and organic unity. The new expression is based on the historical background of the new era. It is the continuation, transcendence and sublimation of building the new rural areas, reflecting inevitable requirement of agricultural development at a new stage and showing re-thinking, re-starting, and re-deployment of the "Three Rural" issues by Party Central Committee (Table 1).

\footnotetext{
4 "Three Modernizations" refers to new industrialization, IT application, and urbanization with Chinese characteristics.

5 "Five-sphere Integrated Plan" is a plan to promote coordinated economic, political, cultural, social, and ecological advancement.
} 
Table 1. Comparison of 20-word policy of building new socialist rural areas and 20-word general requirement for implementing the rural revitalization strategy.

\begin{tabular}{|c|c|c|}
\hline $\begin{array}{l}\text { New Socialist } \\
\text { Rural Areas }\end{array}$ & $\begin{array}{l}\text { Rural Revitalization } \\
\text { Strategy }\end{array}$ & Comparative expression \\
\hline $\begin{array}{l}\text { the production } \\
\text { development }\end{array}$ & thriving businesses & $\begin{array}{l}\text { Development is the basis and key to solving all problems in China. From "development" to "thriving", it } \\
\text { reflects the upgrading of levels and requirements. }\end{array}$ \\
\hline $\begin{array}{l}\text { the village } \\
\text { neatness }\end{array}$ & $\begin{array}{l}\text { Pleasant living } \\
\text { environments }\end{array}$ & $\begin{array}{l}\text { Upgrading from static to dynamic, this emphasizes the building of rural ecological civilization: First, it } \\
\text { expands the village's neatness to the whole ecological environment; second, it cares about people's sense of } \\
\text { gaining and achieves "pleasant living environments". }\end{array}$ \\
\hline $\begin{array}{l}\text { the life } \\
\text { ampleness }\end{array}$ & prosperity & $\begin{array}{l}\text { The urban-rural income gap has further narrowed, and farmers have a steady source of income, economic } \\
\text { well-off, enough to live comfortably, convenient living, and common prosperity. }\end{array}$ \\
\hline $\begin{array}{l}\text { the management } \\
\text { democracy }\end{array}$ & effective governance & $\begin{array}{l}\text { From "management" to "governance", it is the requirement of democracy. "Effectiveness" is the outcome, } \\
\text { which reflects that the emphasis has been shifted from process to outcome. Strengthening and innovating the } \\
\text { new rural social governance can make rural areas more harmonious, stable and orderly }\end{array}$ \\
\hline $\begin{array}{l}\text { the local custom } \\
\text { civilization }\end{array}$ & $\begin{array}{l}\text { social etiquette and } \\
\text { civility, }\end{array}$ & $\begin{array}{l}\text { The building of social etiquette and civility belongs to the fostering stronger observance of socialist cultural } \\
\text { and ethical standards, and it is a long-term process that must be adhered to and enhanced. }\end{array}$ \\
\hline
\end{tabular}

\subsubsection{Integrate with Urban Areas}

Rural revitalization strategy comes up with the "integrated urban-rural development", which is different from the "coordinated urban-rural development "proposed by the 16th National Congress. The "coordinated" proposal deals with issues of "urban haves and rural have-nots" and "the urban-rural gap", like good educational resources, medical resources, infrastructure, etc. It focuses on the coordination and distribution between urban and rural areas, relying on government's leadership and overall planning. While urban-rural integration focuses on the development of symbiosis and co-prosperity in urban and rural areas, relying on entity and major regulation of the market. The 19th National Congress proposes that "we need to put in place sound systems, mechanisms, and policies for promoting integrated urban-rural development", which means that it needs to strengthen the market's role, break administrative monopolies, change the dualistic urban-rural system, and actively develop the rural market. At present, the "urban-rural integration" is accelerating its development, which is typically shown in the migrant workers' returning hometown to start businesses, capital investment to the countryside, and new urbanization.

\subsubsection{Achieve Modernization}

Agricultural modernization is an indispensable and important component of basic and comprehensive modernization. General Secretary Xi Jinping highlights: "The national modernization won't be complete, comprehensive or solid without agricultural modernization, rural prosperity and the well-being of farmers." The rural revitalization strategy follows the "agricultural and rural modernization" set in No. 1 Central Document of 2016. The word "rural" was added at the party congress. First, it emphasizes the importance of rural development. Second, during the rural revitalization, the rural governance needs to follow the sequence system in order to support rural civilization, stability and development. Third, it has higher requirements for the "Three Rural" work which should not be limited to the agricultural modernization, but rather expand to the economic, political, cultural, social, ecological and other aspects.

\section{Scientific Connotation of Rural Revitalization Strategy}

Understanding and seizing the scientific connotation of the rural revitalization strategy is the prerequisite for thoroughly studying and applying Xi Jinping Thought on Socialism with Chinese Characteristics for a New Era and comprehensively implementing the rural revitalization strategy. In order to deeply understand and seize this scientific connotation, it can be analyzed from the following aspects:

\subsection{The Basic Meaning of the Rural Revitalization Strategy}

As socialism with Chinese characteristics has entered a new era and China has embarked on a journey to fully build a modern socialist China, the rural revitalization strategy is based on the new central leadership group with Comrade Xi Jinping as its core and guided by Xi Jinping Thought on Socialism with Chinese Characteristics for a New Era. It focuses on the "Three Rural" issues in the new era and speeds up the agricultural and rural modernization so as to accelerate the advancement from a big agricultural country to a great one. First of all, the leading entity of the strategy is the new central leadership group with Comrade Xi Jinping as the core. The rural revitalization strategy demonstrates that the new central leadership group with Comrade Xi Jinping as the core works on the "Three Rural Issues" through "getting a new look in the new era, and, more importantly, making new accomplishments". Second, the strategy is guided by Xi Jinping Thought on Socialism with Chinese Characteristics for a New Era. The 19th National Congress has "made clear" the socialism with Chinese characteristics in the new era from eight aspects. Third, the strategy makes the new requirements for "Three Rural" work as socialism with Chinese characteristics has entered a new era. Socialism with Chinese characteristics has entered a new era, and the development of agriculture and rural areas has reached a new stage. The urban-rural development has taken on new features, with "Three Rural" issues as the weak point in the building of modernization and serious problems of unbalanced and inadequate development. Fourth, the 
historical task of the strategy is to accelerate the agricultural and rural modernization and to speed up the advancement from a big agricultural country to a great one. It must go along with the building of a great modern socialist country and the realization of the Chinese dream of great national rejuvenation. In the new era, the Party Central Committee with Comrade $\mathrm{Xi}$ Jinping as the core will continue to prioritize the development of agriculture and rural areas, and regard it as an indispensable component of the great national rejuvenation. It will adhere to overall coordination and management, and stick to the prioritized development of agricultural and rural modernization.

\subsection{The General Requirements of the Rural Revitalization Strategy}

First of all, the 20-word general requirement of the strategy is an inseparable organic whole with thriving businesses as its base, pleasant living environments as its foundation, social etiquette and civility as its key, effective governance as its guarantee, and prosperity as its goal. These five aspects are unified in the general requirements of the rural revitalization strategy; Secondly, the general requirement reflects that "China's economy has been transitioning from a phase of rapid growth to a stage of high-quality development" and indicates the new requirements of the agricultural and rural development in the new stage. Since the reform and opening up, the overall agricultural production capacity has been greatly enhanced, the income of farmers has increased remarkably, and the rural appearance has been greatly improved. However, the "Three Rural" issues still remain prominent in the new era, and to solve this problem; Third, the general requirement is in line with the principal contradiction facing Chinese society in the new era. The rural revitalization strategy aims to "keep up with people's ever-growing needs for a better life", bringing rural population with strong sense of fulfillment, happiness, and security.

\subsection{The Main Content of the Rural Revitalization Strategy}

The implementation of the rural revitalization strategy is a systematic strategic project. The main part of the strategy covers the party's emphasis on the "Three Rural" work, the general requirements, key initiatives and specific and essential measures to promote this strategy's implementation. It includes multiple-level aspects such as major urban-rural integration, agricultural and rural modernization, rural land system reform, national food security, the building of modern agriculture's three big systems, development of small household farmers and modern agriculture, the integrated development of the primary, secondary, and tertiary industries in rural areas, integrated governance of "self-governance, rule of law, and rule of virtue" and rural work team with "One Knowledge Two Loves" 6 . More importantly, rural revitalization strategy will make simultaneous advancement

6 "One Knowledge Two Loves" refers to a good knowledge of agriculture, love our rural areas, and love rural people. between industrial and agricultural modernization. It will make urbanization and town-village integration more coordinated, promote the benign interaction of urban and rural resources, and improve the rural areas so as to integrate urban and rural areas into modernization. Therefore, this strategic content is also comprehensive and multifaceted.

\subsection{Key Initiatives of the Rural Revitalization Strategy}

At present, urban -rural development is unbalanced, with rural areas lagging behind. The key measure of this strategy is to build a sound mechanism and policy system for urban-rural development. This is because this initiative of the strategy is based on the priority of agricultural and rural development. In line with the general requirements of the strategy, it serves directly to working faster to achieve agricultural and rural modernization. Therefore, this is the most important move to implement the rural revitalization strategy, which is based on the complete summary of the experience of urban-rural development at home and abroad, and the deliberate consideration of the current and future long-term urban-rural development. Through more than a decade's development, especially since the party's $18^{\text {th }}$ national congress, China has promoted the building of new urban-rural relationship, maintained urban-rural coordination and planned the integrated development with a sound preliminary foundation and a higher level of development, fostering a positive environment of industry nurturing agriculture and cities supporting countryside. However, the level of urban-rural integration is still not high, with the urban-rural dualistic division remaining prominent. To optimally solve this problem, China must take the path of urban-rural integration.

\subsection{The Main Objective of the Rural Revitalization Strategy}

The main objective is to achieve agricultural and rural modernization, which is an important aspect of the country's modernization. It shows that the Party puts the "Three Rural" issues into the China's economic and social unbalanced and inadequate development, and seizes the principal contradiction of socialism with Chinese characteristics in the new era. With higher requirements and a broader perspective, it elevates the agricultural and rural modernization to the same position as urbanization, industrialization, and modernization. At present, to promote the agricultural and rural modernization, the strategy proposes a series of specific policies. With a careful analysis of these policies, it can been seen that they have been reiterated, evolved and innovated. To promote the agricultural and rural modernization, China must adhere to the holistic thinking and full consideration of agriculture and rural areas. It must not only fully consider the modernization of agriculture and comprehensive governance of rural society, and promote all-round economic, political, cultural, social, and ecological progress, but also adhere to coordinated and balanced development and give "agricultural modernization" + "rural modernization" full play to the holistic effect of " $1+1>2$ ". It is necessary to achieve the benign and full development of agriculture, rural areas, and 
rural people, promote the integration of the primary, secondary, and tertiary industries, and accelerate the farmers' innovation and entrepreneurship, and promote the comprehensive governance of rural society.

\section{The Realization Path of Rural Revitalization Strategy}

To further promote the rural revitalization strategy, the following points must be accomplished:

\subsection{Ensure the Top-Level Design and Well Design Strategic Plans}

Plans come first before practice. Based on the agricultural and rural development in this new stage, it is necessary to have a deep understanding of the new features, situations and rules. In order to ensure the top-level design and well design rural revitalization strategic plans, first, the strategy should be promoted comprehensively. the strategic planning should be made in a more sound, holistic and forward-looking way. In accordance with the 20-word general requirement of the rural revitalization strategy, China will start from the establishment of a sound urban-rural integration system and mechanism to further promote the agricultural and rural modernization. Second, the plan should be made systematically. the planning should be made in an adaptable, systematic, and objective way. Basing measures on local circumstances, one should not only prop up the sky by focusing on the needs of the country's overall strategy, but also support the earth by adapting measures on local circumstances and find specific ways to solve problems, to improve the accurate and precise mechanism and implementation of policy. Third, a global perspective should be adopted. China's rural revitalization is an indispensable part of the global rural governance system. The plan must keep an international perspective and focus on the global governance, so as to offer Chinese wisdom and approach to global governance system.

\subsection{Strengthen the System Supply and Promote the Construction of the "Five-Sphere Integrated Plan"}

The rural revitalization strategy is the overall planning, with the system supply as its core. To strengthen the system supply of the rural revitalization strategy, first, China needs to accelerate in putting in place sound systems, mechanisms, and policies for promoting integrated urban-rural development; second, it should focus on rural land system innovation and strengthen the supply of rural land system reform. Third, it should increase the policy support to boost agriculture and benefit farmers, and ensure the national food security system and policy making. Fourth, it must focus on the requirements of agricultural modernization and increase the mechanism of agricultural support and protection. In addition, it should continue to build the mechanism of protecting the farmers' rights and interests, increase the farmers' income, and protect their legitimate rights and interests; it should focus on strengthening foundational work and improve the mechanism of rural governance model which combines self-governance, rule of law, and rule of virtue.

\subsection{Ensure the Principal Status of the People, Serve and Rely on the Rural Population}

The report of the 19th National Congress states: "We must ensure the principal status of the people". By 2020, China will build a moderately prosperous society in all respects, yet there will be tens of millions of people in China waiting to be lift out of poverty. From 2030 to 2050, there will still be nearly 400 million people in rural areas. As farmers are the principal entity to carry out this strategy, the implementation of the rural revitalization strategy needs to rely on hundreds of millions of farmers. It is necessary to fully harness the farmers' enthusiasm, initiative, and creativity. First, China should train professional rural service personnel who have a good knowledge of agriculture, love our rural areas, and care about rural people. Second, it is necessary to carry out our work deeply, meticulously and accurately, and to make the rural revitalization strategy take root. Third, it is essential to serve the rural population and adhere to the farmers' stance, making all the work for the farmers. Fourth, China should make the rural population the most direct beneficiaries of the rural revitalization strategy, providing a bright future for the agriculture, making the agricultural industry attractive, and let the countryside become a fun place.

\subsection{Seize the Core Factors and Ensure Their Free Flows}

To fully implement the rural revitalization strategy, it is necessary to grasp the core elements such as "people", "land" and "money", and let them flow freely. First of all, China should ensure the full flow of the "human". It should continue to promote the transfer of agricultural population and speed up the build of urbanization; it should also pay attention to the structural and aging problems of the rural population, encouraging migrant workers and college students to return to their hometowns to start businesses. Second, China will continue to promote rural land system reform and strengthen the long-term consideration of the collectively owned land parcels of homesteads, profit-oriented and nonprofit public land to serve the rural revitalization strategy. Third, China must encourage capital investment to go to the countryside. It should take safeguarding the fundamental interests of the peasants as the starting point, encourage capital investment to go to the countryside, strengthen financial support for the rural revitalization strategy, and guide social capital to actively participate in the rural revitalization strategy. it requires to promote the urban-rural natural capital appreciation, and integrate urban-rural development. In addition, the rural revitalization strategy needs to rely fully on the science and technology and the market to fully stimulate and release the impetus to implement the rural revitalization strategy. 


\subsection{Ensure the Work Deployment and Promote Steady Growth of the Strategy}

China should take various measures to implement and promote the rural revitalization strategy to achieve stability and long-term stability. In addition to strictly taking the measures for implementing the rural revitalization strategy, the following should be strictly addressed: First, China should find the balance in handling the relationship between the administration and the market. For example, in agriculture, determined by the conditions of more people with less land, small household farming will exist to a certain extent. it should be avoided to speed up the demise of small household farming with human intervention, and leave small household farmers with sufficient space for development. Second, China should fully respect and protect the farmers' rights and interests. For example, in the transfer of agricultural land, it must respect their wishes and protect their rights and interests. their opinion must not be overridden and their rights and interests must not be infringed upon. Third, China should focus on the shortcomings in the development. Especially for those small household poor farmers, vulnerable rural populations, left-behind children, etc., it must provide humanistic care combined with targeted poverty alleviation and the build of an effective social security system. Fourth, China should pay special attention to rural social management It is necessary to strengthen rural foundational work, pursue effective management, and manage to improve the rural governance model which combines self-governance, rule of law, and rule of virtue.

\section{Conclusions}

Based on the rural revitalization strategy proposed by China, this paper analyzes the theoretical logic, scientific connotation and realization path of the rural revitalization strategy. The study shows that the rural revitalization strategy is a new strategy, deployment and requirement for the Party Central Committee's "Three Rural" work in the new era, with "strategy" as its core, "revitalization" as its key, and "rural" as its target. To grasp its scientific connotation, it is necessary to fully understand the essence, general requirements, main objectives and contents of this strategy. To implement this strategy, it is necessary to adhere to the top-level design and well design these strategic plans, to strengthen the system supply and promote the building of the "Five-sphere Integrated Plan". It requires to do more to advance supply-side structural reform in agriculture and work faster to achieve agricultural and rural modernization. It is essential to ensure the principal status of the people and to rely on and serve the rural population. China should grasp the core elements of "people", "land" and "money", and promote steady growth of the rural revitalization strategy.

Coming to a new historical starting point, it is necessary to have a full understanding of the logic of rural revitalization strategy and a deep knowledge of its scientific connotation. The acceleration of the implementation of the strategy will surely enable us to firmly understand the essential features of agricultural development in the current stage and work faster to achieve agricultural and rural modernization and the transfer from a big agricultural country to a great one. The continuous and in-depth advancement of the rural revitalization strategy will surely lay a solid foundation for completing the building of a moderately prosperous society in all respects, take a solid step in striving for the great success of socialism with Chinese characteristics for a new era and energize the realization of the Chinese Dream of national rejuvenation.

\section{References}

[1] Liu Yanshui, Li Yuheng. "Revitelize the world's countryside," Nature, 2017, pp. 275-277.

[2] Han changfu. "Vigorously implementing the strategy of rural revitalization," Beijing: The People's Publishing House, 2017.

[3] Gladwin C H, Long B F, Babb E M, et al. "Rural entrepreneurship: one key to rural revitalization," American Journal of Agricultural Economics, 1989, pp. 1305-1314.

[4] Johnson T G. "Entrepreneurship and development finance: keys to rural revitalization: discussion," American Journal of Agricultural Economics, 1989, pp. 1324-1326.

[5] Korsching P. "Multi-community collaboration: an evolving rural revitalization strategy, " Rural Development News, 1992.

[6] Greene M J. "Agriculture diversification initiatives: state government roles in rural revitalization," Rural Economic Alternatives, 1988.

[7] Ayobami O K, Bin Ismail H N. "Host's supports for voluntourism: a pragmatic approach to rural revitalization," Australian Journal of Basic \& Applied Sciences, 2013.

[8] Kawate T. "Rural revitalization and reform of rural organizations in contemporary rural Japan $[\mathrm{J}]$. Journal of Rural Problems, 2005, pp. 393-402.

[9] Wood, R. E. "Survival of rural America: small victories and bitter Harvests," Univ. Press of Kansas, 2008.

[10] Carr, P. J. \& Kefalas, M. J. "Hollowing out the middle: The rural brain drain and what it means for America," Beacon Press, 2009.

[11] Z Li. "Rural revitalization: Introductions for rural planning and development in east Asia,"2016, pp. 396.

[12] Miletić G M, Golubić M M, Žanić M, et al. "Second home development and rural revitalization: A Case Study from Croatia," European Society for Rural Sociology, 2017.

[13] Nonaka A, Ono H. "Revitalization of rural economies though the restructuring the self-sufficient realm: Growth in small-scale rapeseed production in Japan," Japan Agricultural Research Quarterly, 2015, pp. 383-390.

[14] Bai, X., Shi, P. \& Liu, Y. "Realizing China's Urban dream," Naturem 2014, pp. 158-160. 
[15] McLaughlin, K. "Infectious disease: Scandal clouds China's global vaccine ambitions," Science, 2016, 283: 352.

[16] Liu, Y., Fang, F. \& Li, Y. "Key issues of land use in China and implications for policy making," Land Use Policy, 2014, pp. $6-12$.

[17] Huang jikun. The past and future of Chinese agriculture [J]. World of Management, 2004, pp. 95-104.

[18] Xiang jiquan. "China's rural construction: A century's exploration and path transformation," Journal of Gansu University of Administration," 2009, pp. 87-94.

[19] Huang zuhui, Xu xuchu, Jiang wenhua. "Problems of 'agriculture, rural areas and farmers' in China: Analysis framework, realistic research and judgment, and solutions," China's Rural Economy, 2009, pp. :4-11.

[20] Pan jiayan, Wen tiejun. "Three 'hundred years': the context and development of China's rural construction," Journal of Open Era, 2016, pp. 4-10.

[21] Chen xiwen. "Rural reform and development in China," Science of Leader, 2017, pp. 3-15.

[22] Han jun. "Planning the great chess game of agricultural modernization," Weekly Journal of Agricultural Product Market, 2016, pp. 7-9.

[23] Liu yansui, Yan bin, Wang yanfei. "Major problems of urban and rural development and their transformation strategies in the new era of China," Journal of Economic Geography, 2016, pp. $1-8$.

[24] Wang yong, Li guangbin. "Debate on the decline and revival of rural areas," Planners, 2016, pp. 142-147.

[25] Zhang yong. "Looking at rural problems, urban-rural conflicts and urban-rural integration through the contention of 'doctor's return home during the Spring Festival'," Journal of Theoretical Exploration, 2016, pp. 86-93.

[26] Pan jia'en. "Return home to write: hometown 'problem', or'urban and rural' predicament?" Journal of Cultural Dimension, 2017, pp. 16-16.

[27] Xu yong. "“The root'"and 'the gone with the wind': Imbalance and equilibrium between urban and rural China," Journal of Wuhan University (Humanities Social Edition), 2016, pp. 5-8.
[28] He xuefeng, Wu caijing. "Differentiated rural areas, complex governance," Journal of Yunnan University of Administration, 2016, pp. 4.

[29] Shen mingrui, Shen jianfa, Zhang jingxiang, et al. "Reanalysis of Chinese rural cognition from a comparative perspective: contemporary value and rural Renaissance," Journal of Human Geography, 2015, pp. 53-59.

[30] Shen feiwei, Liu zuyun. "Elite cultivation, order reconstruction and rural renewal," Journal of Humanities 2017, pp. 120-128.

[31] Peng bing. "Countries and villages in the process of marketization: Practice and reflection," Journal of Zhejiang University (humanities and Social Sciences Edition), 2012, pp. 122-130.

[32] Zheng fengtian. "China's urban-rural integration development path selection," Journal of the People, 2016, pp. 70-71.

[33] Liu shouying. “"urban-rural China' from one-way urbanization to urban-rural interaction," Journal of the Rural Work, 2017.

[34] He huili. "The road to rural renewal in contemporary China," People's BBS, Journal of the People, 2012, pp. 52-53.

[35] CAI fang. "Finding a human-centered urbanization path," Journal of Decision Making Exploration, 2017, pp. 22-23.

[36] Zhang hongyu. "Nostalgia should be retained in the construction of beautiful villages," Journal of the People, 2016, pp. 112-112.

[37] Wei guanglong, Cui yunfei. 'Revitalization of 'declining' villages: Research on rural communities in Zhengding County, Hebei Province and research on regeneration construction strategies," Journal of Modern Decoration, 2016.

[38] Zhao Chen. "Remodeling of factor flow environment and active revitalization of villages: An empirical study of 'international slow city' in Dashan village, Gaochun county [J]. Journal of Urban Planning, 2013(3).

[39] Gao huizhi, Zhang jingxiang, Luo zhendong. "Revival or alienation? Transformation of rural space on the edge of metropolis driven by consumption culture: An empirical observation on Gaochun international slow city Dashan village," Journal of International Urban Planning, 2014, pp. 68-73.

[40] Zhang xiaolin. "Differentiation and analysis of rural concept," Acta Geographica Sinica, 1998, pp. 365-370. 